\title{
Pengaruh Interpretasi Konsumen Dalam Bauran Pemasaran Syariah Terhadap Kepuasan dan Loyalitas Konsumen (Studi Kasus Produk Shampo Sari Ayu Hijab) PT. Martina Berto. Tbk. Martha Tilaar)
}

\author{
${ }^{1 *}$ Nurhendra Fatma, ${ }^{2}$ Mukhamad Najib, ${ }^{3}$ Mukhamad Yasid \\ ${ }^{1,2}$ Institut Tazkia Sentul Bogor, Indonesia \\ ${ }^{3}$ Departemen Manajemen Institut pertanian Bogor (IPB), Indonesia \\ *Email korenpondensi: zaskiafatma@yahoo.com
}

\begin{abstract}
Perception is an activity that contains, viewing, imaging, expecting and valuing both physical and social objects. A positive perception towards object will have a positive impact on these objects. Perception is more important than reality in marketing, because it can influence consumer's behavior. Different people can have different perceptions for the same object, so that a suitable marketing strategy is needed to win consumers. To formulate suitable marketing strategy, company identifies consumer desires, needs, requests, decisions, and trust level to the company before manufacturing products. The purpose of this study is to analyze consumer perceptions of Sariayu Hijab Shampoo using sharia marketing mix and to study the relationship between customer satisfaction and loyalty. Data is collected through questionnaire and sampling methodology is using purposive sampling and respondents are Muslimah Students in East Jakarta. Descriptive analysis using cross tabulation and statistical tests performed using SEM-PLS. This study found that consumer perceptions towards Sariayu Shampoo Hijab is good. Sharia Marketing Mix has positive relationship and significant effect on consumer satisfaction. The dominant variables are product and direct distribution have direct effect to customer satisfaction. While price and indirect promotion have no direct effect to customer satisfaction. Consumer loyalty has positive relationship through customer satisfaction (product and distribution)
\end{abstract}

Keywords: SEM-PLS, Sharia Marketing Mix,Satisfaction, Loyalty

Abstrak
Persepsi merupakan sebuah aktivitas berupa, pandangan, gambaran,harapan serta memberikan
penilaian terhadap objek-objek fisik ataupun sosial. Jika penilaian dan harapan terhadap sesuatu
barang dan jasa itu baik maka, akan berdampak positif, karena persepsi yang baik dapat
mempengaruhi konsumen dalam berperilaku. Strategi pemasaran yang tepat dalam merebut konsumen
diperlukan. Sebelum menentukan strategi sebaiknya perusahaan mengidentifikasikan keinginan
konsumen, kebutuhaan, permintaan dan keputusan, dan kepercayaan terhadap perusahaan dengan
cara menentukan barang yang akan diproduksi. Tujuan penelitian ini adalah mengetahui persepsi
konsumen terhadap Shampo Sariayu Hijab dalam bauran pemasaran syariah dan mengetahui
hubungan antara kepuasan dan loyalitas konsumen. Data dikumpulkan menggunakan metode
purposive sampling. Alat penelitian berupa kuesioner, responden mahasiswi muslimah yang berada di
Wilayah Jakarta Timur. Analisis deskritif data menggunakan tabulasi silang, serta uji statistik
dilakukan dengan SEM-PLS.Dari hasil penelitian ini ditemukan bahwa persepsi konsumen terhadap
Shampo Sariayu Hijab memberikan penilaian yang baik. Bauran Pemasaran Syariah mempunyai
hubungan positif dan berpengaruh signifikan terhadap kepuasan konsumen, variabel yang dominan
adalah produk dan distribusi berpengaruh langsung terhadap kepuasan konsumen, sedangkan
variabel harga dan promosi tidak berpengaruh langsung terhadap kepuasan konsumen. Loyalitas


konsumen mempunyai hubungan yang positif melalui kepuasaan konsumen adalah variabel produk dan variabel distribusi.

\section{Kata kunci: SEM-PLS Bauran Pemasaran Syariah, Kepuasan, Loyalitas}

Saran sitasi: Fatma, N., Najib, M., \& Yasid, M. (2019). Pengaruh Interpretasi Konsumen Dalam Bauran Pemasaran Syariah Terhadap Kepuasan dan Loyalitas Konsumen (Studi Kasus Produk Shampo Sari Ayu Hijab) PT. Martina Berto. Tbk. Martha Tilaar). Jurnal Ilmiah Ekonomi Islam, 5(03), 277-291. doi: http://dx.doi.org/10.29040/jiei.v5i3.673

\section{DOI: $\underline{\text { http://dx.doi.org/10.29040/jiei.v5i3.673 }}$}

\section{Pendahuluan}

PT Martina Berto.T.bk mengeluarkan produk baru Shampo Sariayu Hijab yang bersetifikat halal, Produk andalan dari Sariayu Martha Tilaar. Adanya sertifikasi halal dari LPPOM MUI konsumen akan lebih nyaman dan yakin untuk menggunakan produk-produk dari Martha Tilaar. Pemasar harus menciptakan peluang dan manfaat untuk maju dan berada digaris depan. Dalam mengisi peluang dituntut kejelian perusahaan agar tercipta usaha yang memiliki nilai lebih. Berdasarkan hasil riset terakhir oleh AC Nielsen, faktor kesamaan iklim, sosial budaya, daya beli, berpotensi membuat konsumen Asean memiliki preferensi yang sama dengan konsumen Indonesia. Hal ini dapat menjadi pendorong bagi produk kosmetik di Indonesia untuk diterima dengan baik di pasar Asean. Berdasarkan Survei Bizteka-CCI, kenaikan rata-rata persentase pertahun mencapai 9.67\%. Perkembangan pasar industri kosmentik Indonesia sebagai mana terlihat dalam grafik di bawah ini;

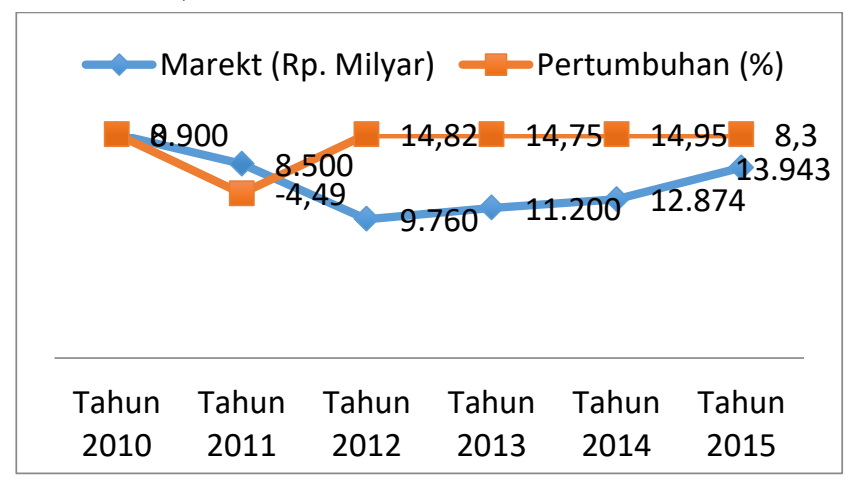

Sumber: Survey Bizteka - CCI

Gambar 1. Perkembangan Pasar Industri

Kosmetik Indonesia (2010 -015)
Gambar 1, merupakan data perkembangan perusahaan industri kosmetik yang ada di Indonesia, dari data tersebut dapat diambil kesimpulan, pertumbuhannya dari tahun ketahun terus meningkat. Maka ini peluang besar untuk perusahaan industri kosmetik untuk mengelola perusahaannya agar profesional dalam dunia bisnis. Dibutuhkan program pemasaran yang komprehensif, taktik, nilai (value) dari produkproduk agar dapat diterima dengan baik dengan terobosan pemasaran yang konsisten dan terintegrasi

Pemasaran Syariah merupakan penerapan suatu disiplin bisnis strategi yang sesuai dengan nilai dan prinsip serta dijalankan dengan konsep keIslaman yang telah diajarkan oleh Nabi Muhammad SAW. Dalam Syariah Marketingseluruh proses baik proses penciptaan, proses penawaran maupun proses perubahaan nilai (value) tidak boleh ada hal-hal yang bertentangan dengan akad dan prinsip muamalah. Syariah Islam universal. Komprehensif berarti seluruh aspek kehidupan baik ibadah maupun sosial (muamallah). Ibadah diperlukan untuk menjaga ketaatan dan keharmonisan hubungan manusia dengan khaliqNya. Ibadah juga merupakan sarana untuk mengingatkan tugas manusia sebagai khalifah-Nya dimuka bumi. Sebagimana dalam QS Al Jumu'ah ayat 10:

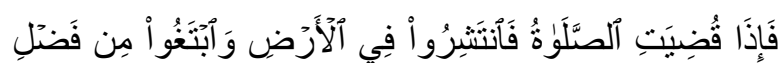

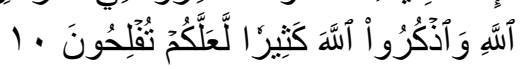

Artinya: Apabila telah ditunaikan shalat, maka bertebaranlah kamu di muka bumi; dan carilah 
karunia Allah dan ingatlah Allah banyak-banyak supaya kamu beruntung. (Al Jumu'ah ayat 10)

Menurut Alserhan (2011) Pemasaran Islam mempelajari bagaimana perilaku pasar orang Islam yang dibentuk oleh berbagai konsep relijius dan budaya yang mempengaruhi hampir semua keputusan ekonomi di pasar. Sedangkan menurut Alom dan Haque (2011) mendefinisikan Pemasaran Islam sebagai proses dan strategi tentang pemenuhan kebutuhan melalui produk dan jasa halal thayyibat dengan persetujuan timbal balik (bersama) dan kesejahteraan falah bagi kedua belah pihak untuk tujuan mencapai kesejahteraan material dan spiritual dunia dan akhirat Menurut Kartajaya dan Sula (2008) syariah marketing adalah sebuah disiplin bisnis strategis yang mengarahkan proses penciptaan, penawaran dan perubahan value dari suatu inisiator kepada stakeholders-nya, yang dalam keseluruhan prosesnya sesuai dengan akad dan prinsip-prinsip muamallah (bisnis) dalam Islam. Empat (4) Karakteristik Syariah yang dimaksudmenurut Kartajaya dan Sula (2008) adalah sebagai berikut:

a. Teistis (rabbâniyyah):

Syariah marketing adalah sifatnya yang religius dîniyyah,bersifat ketuhanan ini adalah hukum yang paling adil, paling sempurna, paling selaras dengan segala bentuk kebaikan, paling dapat mencegah segala bentuk kerusakan, paling mampu mewujudkan kebenaran, memusnahkan kebatilan dan menyebarluaskan kemaslahatan.

b. Etis (akhlâqiyyah):

Syariah marketer karena sangat mengedepankan masalah akhlak moral, etika dalam seluruh aspek kegiatannya. Karena nilai-nilai moral dan etika adalah nilai yang bersifat universal, yang diajarkan oleh semua agama.

c. Realistis (al-wâqi'iyyah):

Syariah marketing bukanlah konsep yang eksklusif, fanatis, anti modernitas,dan kaku. Syariah marketing adalah konsep pemasaran yang fleksibel, sebagaimana keluasan dan keluwesan Syariah Islamiyah yang melandasinya. Syariah Marketer. Bekerja dengan professional dan mengedepankan nilai-nilai religius, kesalehan, aspek moral dan kejujuran dalam segala aktivitas pemasarannya.

\section{d. Humanistis (insaniyyah):}

Syariah Marketing yang lain adalah sifatnya yang humanistis universal, yaitu bahwa syariah diciptakan untuk manusia agar derajatnya terangkat, sifat kemanusiaannya terjaga dan terpelihara, serta sifat-sifat kehewanannya dapat terkekang dengan panduan syariah. Syariat Islam diciptakan untuk manusia sesuai dengan kapasitasnya tanpa menghiraukan ras, warna kulit, kebangsaan dan status. Hal inilah yang membuat syariah memiliki sifat universal sehingga menjadi syariah humanistis universal.

Dalam pemasaran terdapat strategi pemasaran yang disebut bauran pemasaran (marketing mix), yang memiliki peranan penting dalam mempengaruhi konsumen agar membeli produk yang ditawarkan oleh perusahaan.Untuk lebih jelasnya berikut ini definisibauran pemasaran, menurut para Ahli pemasaran yaitu: Bauran pemasaran menurut Benyamin Molan (2012) dapat diartikan bauran pemasaran (marketing mix) adalah perangkat alat pemasaran yang digunakan perusahaan untuk mengejar tujuan pemasarannya.sedangkan menurut Kotler \& Keller (2012) Marketing mix terdiri atas empat komponen atau disebut 4P yaitu product, price, place, promotion." Strategi marketing mix yang umumnya dikenal dengan nama bauran pemasaran, diformulasikan konsep 4P (Produk,Price,Place,Promosi,).Menurut Ramiz (2014) menyatakan kepuasan konsumen sebagai evaluasi pasca konsumsi terhadap produk atau layanan dalam hal sikap positif atau netral atau negatif terhadap produk atau layanan yang dihasilkan dari korespondensi yang menguntungkan antara harapan konsumen dan pengalaman dengan perusahaan atau produknya. 
Definisi kepuasan pelanggan menurut Kotler (2014) adalah: Perasaan senang atau kecewa yang muncul setelah membandingkan kinerja (hasil) produk yang dipikirkan terhadap kinerja (atau hasil) yang diharapkan. Menurut Zulfa (2010). Loyalitas pelanggan dalam Islam terjadi apabila aktivitas muamalah dapat memberi manfaat yang saling menguntungkan kedua belah pihak, karena terpenuhinya kewajiban serta hak masing-masing melalui penerapan nilai-nilai Islam. Sedangkan menurut Ganiyu (2012) menyatakan bahwa kepuasan konsumen dan loyalitas tidak berhubungan langsung karena terdapat perbedaan besar antara kepuasan dan loyalitas, dimana kepuasan merupakan kondisi konsumen yang pasif sedangkan loyalitas merupakan kondisi konsumen yang aktif.

Kerangka pemikiran pada penelitian ini diambil dari berbagai teori yang relevan, antara lain teori Bauran Pemasaran, Karakteristik Pemasaran Syariah Kepuasan dan Loyalitas Konsumen. Alur penelitian dapat dilihat pada gambar berikut:

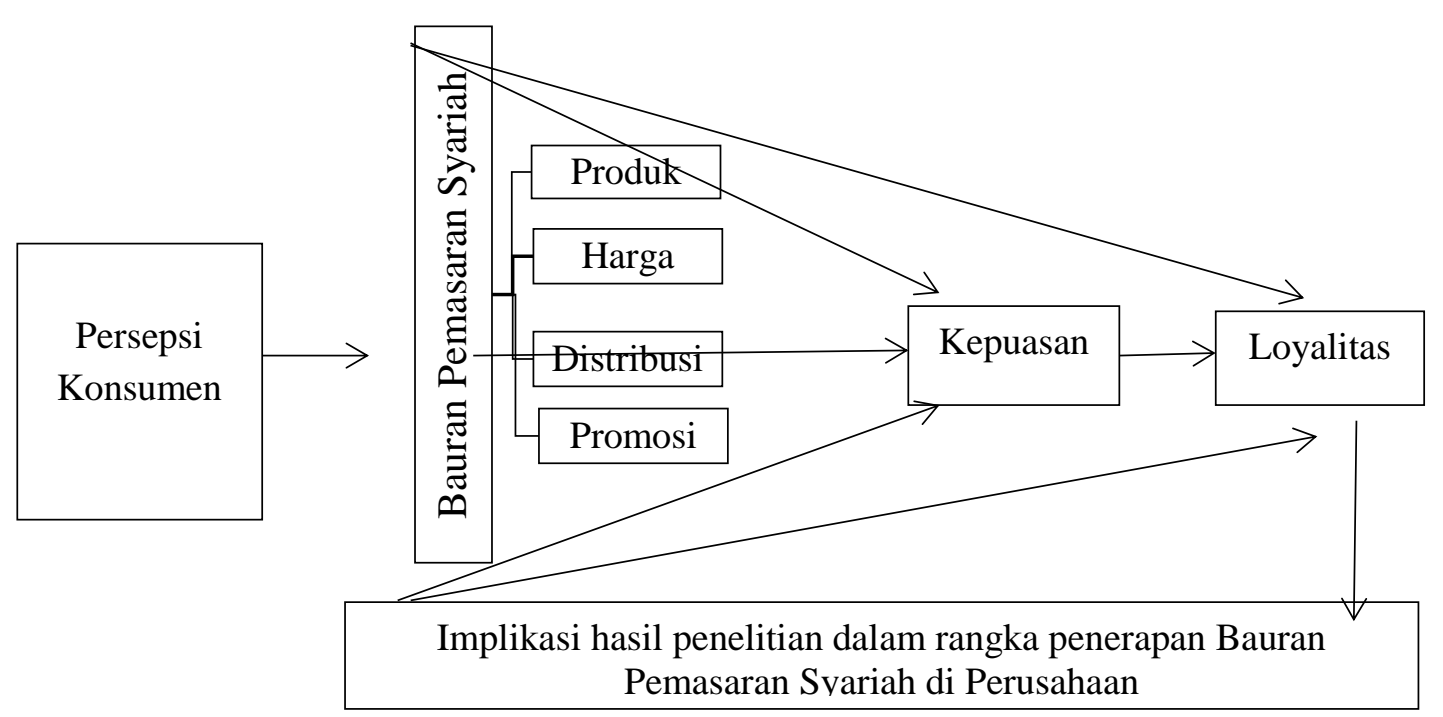

Gambar 2. Proses Alur dalam Penelitian

\section{Hipotesa:}

H1. Produk berpengaruh terhadap Kepuasan dan Loyalitas Konsumen

H2. Harga berpengaruh terhadap Kepuasan dan Loyalitas Konsumen

H3. Distribusi berpengaruh terhadap Kepuasan dan Loyalitas Konsumen

H4. Promosi berpengaruh terhadap Kepuasan dan loyalitas Konsumen

H5. Kepuasan terhadap Loyalitas Konsumen

\section{Metode Penelitian}

\subsection{Metode Pengambilan Sampel}

Dalam penelitian ini, populasi didefinisikan sebagai mahasiswa yang menggunakan produk Shampo Sariayu Hijab dan sampel yang diambil menggunakan teknik Purposive Sampling dan Random Sampling.
Menurut Sugiyono (2012) Purposive sampling adalah: teknik yang digunakan dalam penentuaan sampel dengan pertimbangan tertentu. Dan RandomSampling adalah: pengambilan sampel anggota populasi dilakukan secara acak tanpa memperhatikan starta yang ada dalam populasi tersebut. Hal ini dilakukan karena anggota populasi dianggap homogen. Berdasarkan populasi yang ada, sampel yang diambil dalam penelitian ini secara acak sebanyak 100 orang konsumen mahasiswa muslimah yang pernah menggunakan Shampo Sariayu Hijab, dari empat Universitas di Wilayah Jakarta Timur. yakni: Univeristas Islam Jakarta, Universitas Aassafiah dan Univeritas Darmapersada Univeritas Jayabaya. 
2.2. Metode Pengolahaan dan Analisis Data. Uji Instrumen Penelitian yang terdiri dari 1). Uji Validitas

Menggunakan program SPSS 13.00 for windows .2).Uji Reabilitas,. Pengukuran dikatakan reliabel jika memberikan nilai Cronbach Alpha > 06.3). Deskriptif Data. Gambaran informasi data yang didapat dari lapangan melalui jawaban responden dari kuesioner yang disebar, disajikan dalam bentuk persentase tabulasi tabel dan grafik.4.) Uji Statistik, dilakukan dengan SEM-PLS dengan 2 tahapan Pemodelan yaitu: 1).Model structural
(Inner model) yaitu model struktural yang menghubungkan antar variabel laten. 2)Model Measurement (Outer Model) yaitu model pengukuran yang menghubungkan indikator dengan variabel latennya.

\subsection{Definisi Variabel}

Penelitianmenguji persepsi konsumen dalam bauran pemasaran syariah terhadap kepuasan dan loyalitas konsumen pada Shampo Sariayu Hijab. Berdasarkan Kajian Teori, ada beberapa variabel yang menjadi pokok permasalahan yang akandianalisis sebagai berikut:

Tabel 1. Definisi Variabel

\begin{tabular}{|c|c|c|}
\hline Variabel laten & Variabel Indikator & Karakteristik Pemasaran Syariah \\
\hline $\begin{array}{l}\text { Produk }\left(\xi_{1}\right) \\
\text { Al Muslih }(2004,331-386), \text { Shafie \& } \\
\text { Othman }(2013)\end{array}$ & $\begin{array}{l}\text { 1.Halal }\left(X_{11}\right) \\
\text { 2.Baik }\left(X_{12}\right) \\
\text { 3.Manfaat }\left(X_{13}\right) \\
\end{array}$ & $\begin{array}{l}\text { Bersifat ketuhanan } \\
\text { Teistis }\end{array}$ \\
\hline $\begin{array}{l}\text { Price) }\left(\xi_{2}\right) \text { Suwarni dan Mayasari }(2011) \\
\text { Al Ghazali }(450 \mathrm{H} / 1058 \mathrm{M}-505 \mathrm{H} / 1111 \mathrm{M})\end{array}$ & $\begin{array}{l}\text { Terjangkau }\left(X_{21}\right) \\
\text { Tidak Zalim }\left(X_{22}\right)\end{array}$ & $\begin{array}{l}\text { Realistis dalam aspek penentuan } \\
\text { harga }\end{array}$ \\
\hline $\begin{array}{l}\text { Distribusi }\left(\xi_{3}\right) \\
\text { Tjiptono }(2008: 185 \\
\text { Menurut Sukatjo dan Radix (2010), }\end{array}$ & $\begin{array}{l}\text { Kelancaran }\left(X_{31}\right) \\
\text { Tepat waktu }\left(X_{32}\right) \\
\text { Mudah }\left(X_{33)}\right.\end{array}$ & $\begin{array}{l}\text { Etis,memiliki etika,moral dalam } \\
\text { mendistibusikan barang }\end{array}$ \\
\hline $\begin{array}{l}\text { Promosi }\left(\xi_{4}\right) \\
\text { (Haque et al: 2010). }\end{array}$ & $\begin{array}{l}\text { 1.Iklan }\left(X_{41}\right) \\
\text { 2.Informasi }\left(X_{42}\right) \\
\text { 3.Mengingatkan }\left(X_{43}\right) \\
\end{array}$ & $\begin{array}{l}\text { Etis,memiliki etika,moral dalam } \\
\text { promosi }\end{array}$ \\
\hline $\begin{array}{l}\text { Kepuasan konsumen }\left(\eta_{1)}\right. \\
\text { Lupiyoadi, dkk (2008) } \\
\text { Kotler }(2014) \\
\end{array}$ & $\begin{array}{l}\text { Respon Positif }\left(Y_{11}\right) \\
\operatorname{Empati}\left(Y_{12}\right) \\
\operatorname{Terjamin}\left(Y_{13}\right)\end{array}$ & $\begin{array}{l}\text { Humaitis,sifat kemanusia ,memiliki } \\
\text { dan kepedulian terhadap kebutuhan } \\
\text { konsumen }\end{array}$ \\
\hline $\begin{array}{l}\text { Loyalitas Konsumen }\left(\eta_{1)}\right. \\
\text { Sasmita dan Suki }(2015)\end{array}$ & $\begin{array}{l}\text { Pembelian ulang }\left(Y_{21}\right) \\
\text { Rekomendasikan pada } \\
\text { orang lain }\left(Y_{22}\right) \\
\text { Pelanggan }\left(Y_{23}\right)\end{array}$ & $\begin{array}{l}\text { Humaitis,memiliki dan kepedulian } \\
\text { terhadap kebutuhan konsumen }\end{array}$ \\
\hline
\end{tabular}

\section{Keterangan:}

$\xi:$ variabel laten independen

$\eta$ :variabel laten dependen

$X:$ variabel manifest independen

$Y$ : variabel manifest dependen

$\sum$ : kekeliruan model pengukuran variabel eksogen

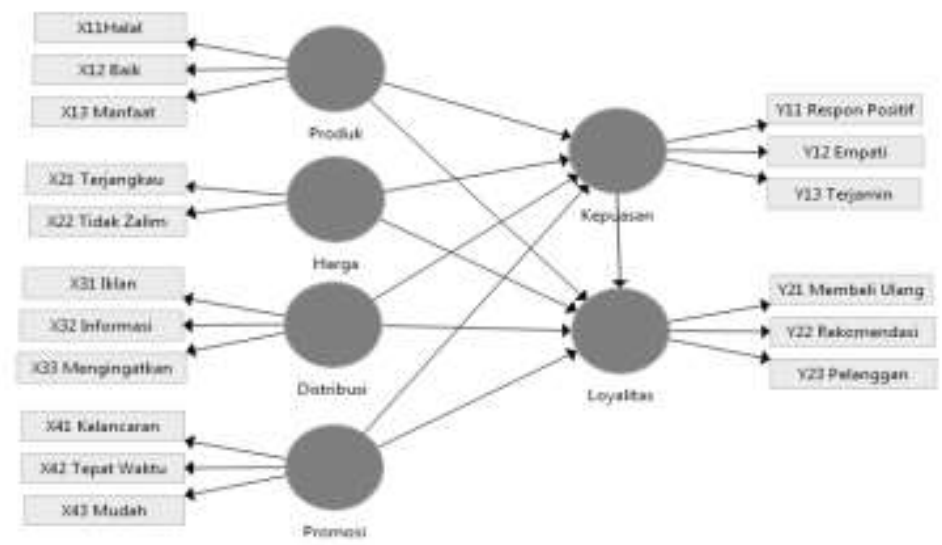

Sumber : Diolah Penulis (Software SemPLS3)

Gambar 3. Rancangan Structural Equation Modelling 


\section{Hasil dan Pembahasan}

\subsection{Hasil}

\section{a. Uji instrument}

Uji validitas membanding nilai $t_{\text {hitung }}$ dan $t$ tabel) pada taraf signifikansi $(\alpha=0,05)$ didapat $\mathrm{t}$ tabel 0,163 , artinya bila $t_{\text {hitung }}>\mathrm{t}_{\mathrm{t}}$ abel maka butir instrument atau pertanyaan valid dan sebaliknya bila $t_{t}$ hitung $<\mathrm{t}$ tabel instrumen tidak valid.40 butir pertanyaan semua mempunyaai nilai $\mathrm{t}$ hitung diatas >t- tabel $(0,163)$ dan semua $t$ bernilai positif. Sehingga bisa dikatakan seluruh butir pertanyaan adalah valid, dapat digunakan untuk menganalisis.

Uji reabilitas hasil perhitunganya dapat dilihat pada tabel dibawah ini:

Tabel 2. Rekapitulasi Cronbach's Alpha Uji Reabilitas

\begin{tabular}{|c|l|c|c|c|}
\hline No & \multicolumn{1}{|c|}{ Indikator } & Cronbach's Alpha & N of Items & Keterangan \\
\hline 1 & Produk Halal & 0,765 & 3 & Realiabel \\
\hline 2 & Produk Baik & 0,754 & 4 & Realiabel \\
\hline 3 & Produk Manfaat & 0,853 & 3 & Realiabel \\
\hline 4 & Harga Terjangkau & 0,881 & 3 & Realiabel \\
\hline 5 & Harga Tidak zalim & 0,738 & 3 & Realiabel \\
\hline 6 & Distribusi Kelancaran & 0,860 & 3 & Realiabel \\
\hline 7 & Distribusi Tepat Waktu & 0,867 & 2 & Realiabel \\
\hline 8 & Distribusi Mudah & 0,872 & 2 & Realiabel \\
\hline 9 & Promosi Iklan & 0,731 & 4 & Realiabel \\
\hline 10 & Promosi Informasi & 0,800 & 2 & Realiabel \\
\hline 11 & Promosi Mengingatkan & 0,890 & 4 & Realiabel \\
\hline 12 & Kepuasan Respon Positif & 0,862 & 1 & Realiabel \\
\hline 13 & Kepuasan Empati & 0,862 & 1 & Realiabel \\
\hline 14 & Kepuasan Terjamin & 0,862 & 1 & Realiabel \\
\hline 15 & Loyalitas Pembelian Ulang & 0,873 & 2 & Realiabel \\
\hline 16 & Loyalitas Rekomendasi & 0,873 & 1 & Realiabel \\
\hline 17 & Loyalitas Pelanggan & 0,873 & 1 & Realiabel \\
\hline
\end{tabular}

Sumber: diolah penulis, Spss 13.00

Tabel di atas menunjukan adanya korelasi yang positif disetiap variabel dengan 40 butir pertanyaan/pernyataan, semua mempunyai nilai $r$ hitung diatas $r$ tabel nilai $r$ tabel $(5 \%)=0,163$ sehingga bisa dikatakan seluruh variabel dinyatakan realibel dapat digunakan untuk menganalisis pada tahapan selanjutnya.

\section{b. Deskriptif Data}

Karakteristik Responden. Informasi data yang didapat dari lapangan melalui jawaban responden dari kuesioner yang disebar, disajikan dalam bentuk persentase tabulasi tabel dan grafik. Kuesioner ini terdiri dari 6 variabel, 17 indikator dan 40 butir pernyataan, Persepsi konsumen terhadap Shampo Hijab Sariayu secara keseluruhaan baik. Dari 100 responden 57 orang konsumen menyatakan setuju bahwa Shampo Sariayu Hijab terbuat dari bahan yang halal, baik dan bermanfaat untuk rambut mereka.

64 orang konsumen menyatakan setuju bahwa harga Shampo Sariayu Hijab sesuai dengan kualitas ,stabil dan harganya terjangkau. Dan 50 orang konsumen menyatakan setuju bahwa promosi yang dilakukan Shampo Sariayu Hijab sesuai dengan promosi yang Islami. Serta 57 orang konsumen juga menyatakan setuju bahwa distribusi yang dilakukan Shampo Sariayu Hijab lancar dan barang yang sampai ketangan konsumen dipastikan aman dan terhindar dari pemalsuaan. 


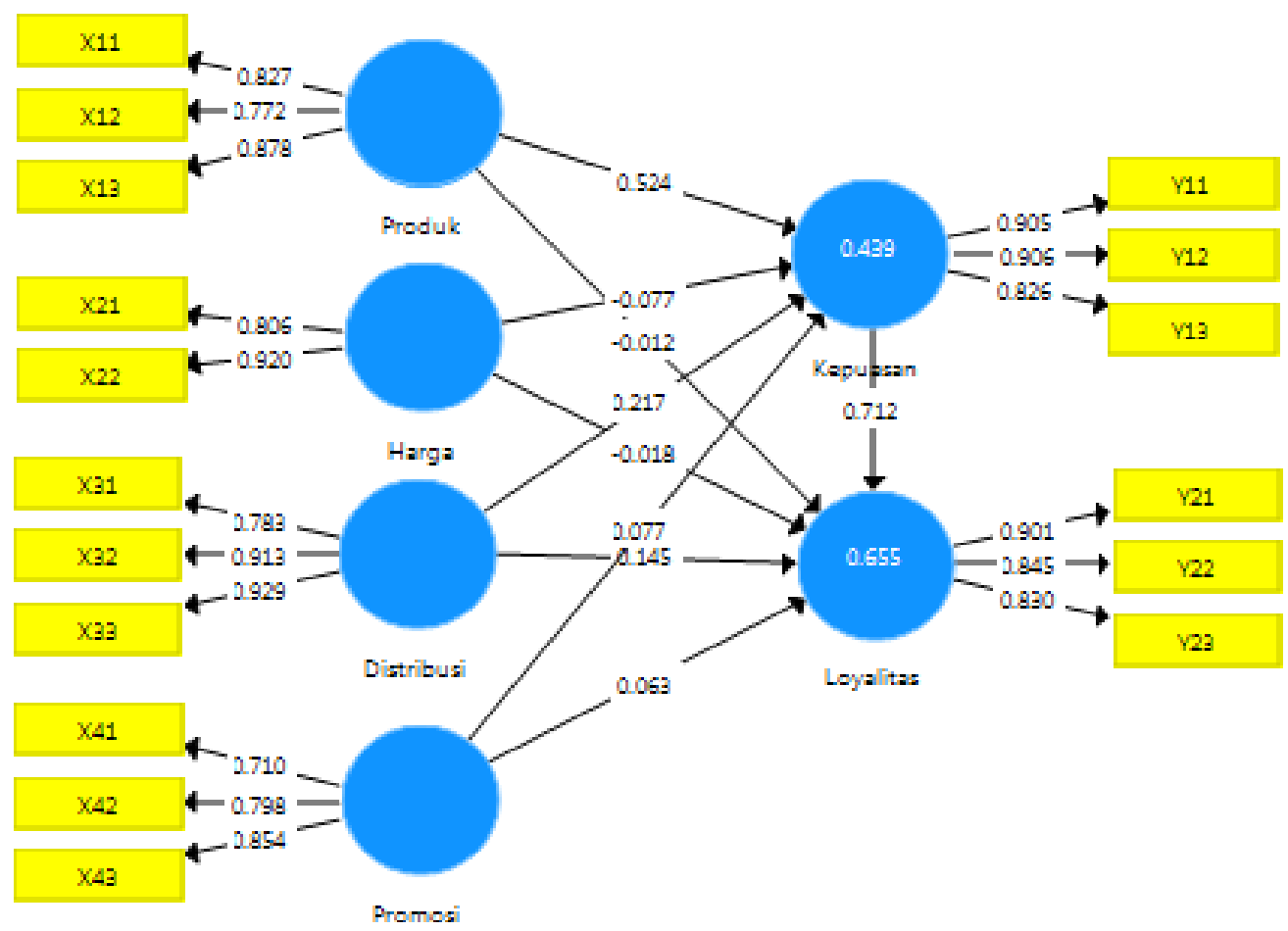

Gambar 4. Path Model Hasil Estimasi Model Outer Loadings

Uji Statistik. Gambar diatas merupakan analisis model. pengukuran hubungan antara variabel laten dengan indikatornya(Outer Model) dan hubungan antara variabel laten (Inner Model) .Gambar diatas menunjukkan bahwa seluruh variabel indikator yang digunakan untuk mengukur variabel laten eksogen (produk, harga, tempat, dan promosi) dan variabel laten endogen (kepuasan dan loyalitas) menunjukkan hasil yang signifikan.

Hal ini dapat dilihat dari seluruh variabel indikator memiliki nilai t-statistik > t-tabel 1.96 untuk taraf signifikansi 0.05. dan nilai CR dan AVE > 0.70, dengan demikian seluruh variabel indikator yang digunakan untuk mengukur variabel laten eksogen dan variabel laten endogen telah valid dan reliable, dan tidak ada indikator yang dihilangkan dalam model estimasi, karena telah memenuhi stadar nilai yang diharapkan atau menyatakan hasil yang cocok (fit.) dapat digunakan untuk menganalisa dan menarik kesimpulan. Dan artinya gambar 1 sudah menjadi model akhir.

\subsection{Pembahasan}

a. Uji Kecocokan Model Pengukuran (Outer Model)
Pada variabel produk indikator yang paling tinggi nilainya adalah indikator manfaat dengan nilai sebesar 0.8778 , diikuti oleh indikator halal dan baik, ini sesuai dengan tanggapan responden dari hasil tabulasi silang yang menyatakan pada butir satu responden mejawab setuju sebanyak 57 orang. Hal ini sesuai dengan penelitian yang dilakukan oleh Harjati dan Sabu G (2014). Produk yang bisa memberikan manfaat yang terbuat dari bahan alami dan natural bisa mempengaruhi nilai-nilai, sikap dan perilaku konsumen yang berkaitan dengan produk tersebut, dan penelitan yang dilakukan oleh Shafie \& Othman (2013) produk yang berkualitas dan mampu memenuhi kebutuhaan konsumen serta memperhatikan aturan mualamalah bisnis adalah produk yang dicari dan dibutuhkan, bahwa produk yang halal atau mempunyai logo halal merupakan suatu produk yang memberikan jaminan kepada konsumen yang membuat mereka merasa tenang dan nyaman.

Pada variabel harga indikator yang paling tinggi nilainya adalah indikator tidak zalim dengan nilai sebesar 0.9202. Artinya harga Shampo Sariayu Hijab cukup adil dan masih 
stabil jika dibandingkan dengan harga produk shampo sejenis, diikuti oleh indikator terjangkau, ini sesuai dengan tanggapan responden pada pernyataan butir 13, bahwa produk Shampo Sariayu Hijab sesuai dengan kwalitas yang ditawarkan,dan mengindikasikan bahwa responden tidak mempermasalahkan harga Shampo Sariayu Hijab dan responden memberikan tanggapan yang baik terhadap kebijakan harga yang ditetapkan oleh Shampo Sariayu Hijab. Hal ini sesuai dengan pendapat Suwarni dan Mayasari (2011) harga yang terjangkau dan kwalitas yang baik memungkinkan adanya kepuasan konsumen dan akan menarik konsumen baru sehingga diharapkan konsumen akan loyal.

Pada variabel distribusi indikator yang paling tinggi nilainya adalah indikator mudah dengan angka sebesar 0.9288, diikuti oleh indikator tepat waktu. Artinya Shampo Sariayu Hijab mudah didapatkan jika konsumen membutuhkan. Hal ini sesuai dengan pendapat Tjiptono (2008), menyatakan secara garis besar, pendistribusian dapat diartikan sebagai kegiatan pemasaran yang berusaha memperlancar dan mempermudah penyampaian barang dan jasa dari produsen kepada konsumen, sehingga penggunaannya sesuai dengan yang diperlukan (jenis, jumlah, harga, tempat, dan saat dibutuhkan).

Pada variabel promosi indikator yang paling tinggi nilainya adalah indikator mengingatkan dengan nilai sebesar 0.8537. Sesuai dengan tanggapan responden pada butir 21 mengatakan bahwa Shampo Sariayu Hijab memperhatikan tanggal kadaluarsa dan waktu produksi 64 responden mengatakan setuju, dan responden juga mengatakan Shampo Sariayu Hijab konsisten, jujur dalam melakukan promosi sehingga informasi tentang Shampo Sariayu Hijab mampu mengingatkan konsumen.

Artinya promosi yang dilakukan oleh Shampo Sariayu Hijab cukup efektif dan efisien. Hal ini sesuai dengan pendapat Abdullah dan Ahmad, (2010) salah satu tujuan promosi dalam periklanan adalah untuk memberitahukan atau mendidik konsumen ditambahkan oleh Wijaya dan Dharmayanti (2014) semakin baik informasi iklan maka semakin baik pula pengenalan merek /produk di benak konsumen.

Pada variabel kepuasan indikator yang paling tinggi nilainya adalah indikator empati dengan angka sebesar 0.9060, diikuti oleh indikator respon positif, hal ini sesuai dengan hasil pada tabel silang sebanyak 44 responden mengatakan setuju Shampo Sariayu Hijab memenuhi kebutuhan konsumen akan produk halal. Sejalan pendapat Ramiz (2014) menyatakan kepuasan konsumen sebagai evaluasi pasca konsumsi terhadap produk atau layanan dalam hal sikap positif atau netral atau negatif terhadap produk atau layanan yang dihasilkan dari korespondensi yang menguntungkan antara harapan konsumen dan pengalaman dengan perusahaan atau produknya.

Ditambahkan oleh Kotler (2014) kepuasan adalah: Perasaan senang atau kecewa yang muncul setelah membandingkan kinerja (hasil) produk yang dipikirkan terhadap kinerja (atau hasil) yang diharapkan

Pada variabel loyalitas indikator yang paling tinggi nilainya adalah indikator pembelian ulang dengan angka sebesar 0.9013, diikuti oleh indikator merekomendasikan pada orang lain artinya loyalitas konsumen akan tercipta jika konsumen mampu melakukan pembelian ulang dan merekomendasikanya pada orang lain. Ditambakan oleh Sasmita dan Suki (2015) menyatakan bahwa karakteristik konsumen setia adalah preferensi dan konsistensi untuk membeli produk atau layanan, konsumen menginfomasikan, menghubungkan secara informal ke teman, keluarga dan calon konsumen potensial lainnya.

\section{b. Uji Kecocokan Model Structural (Inner Model)}

Hubungan antara variabel laten bauran pemasaran syariah dengan variabel kepuasan dan loyalitas terjadi pada model struktural. Hubungan tersebut memperlihatkan keeratan hubungan antar variabel laten. Bauran pemasaran yang 
mempengaruhi kepuasan dan loyalitas konsumen. Kriteria uji inner model sebagai berikut:

\section{c. Nilai Koefisien Determinasi}

Hasil perhitungan nilai koefisien determinasi ( $\mathrm{R}^{2}$ atau $\mathrm{R}$-square) dapat dilihat pada tabel berikut:

Tabel 3. R Square

\begin{tabular}{|l|c|c|}
\hline Variabel laten & R Square & R Square Adjust \\
\hline Kepuasan & 0.4394 & 0.4158 \\
\hline Loyalitas & 0.6554 & 0.6371 \\
\hline
\end{tabular}

Sumber: diolah penulis (Software SEMPLS3)

Tabel di atas menunjukan nilai $\mathrm{R}$ Square kepuasaan sebesar 0.4394, dapat dijelaskan bahwa, produk $\left(\mathrm{X}_{1}\right)$, harga $\left(\mathrm{X}_{2}\right)$, distribusi $\left(\mathrm{X}_{3}\right)$ promosi $\left(\mathrm{X}_{4}\right)$. terhadap kepuasan $\left(\mathrm{Y}_{1}\right)$ memberikan nilai 0.4394 yang dapat diinterprestasikan bahwa kepuasan konsumen dapat dijelaskan oleh variabel bauran pemasaran syariah 43,94 \% sedangkan sisanya sisanya $56.06 \%$ dijelaskan oleh variabel lain di luar penelitian.

Nilai R Square untuk loyalitas sebesar 0.6554, dapat dijelaskan bahwa produk $\left(\mathrm{X}_{1}\right)$, harga $\left(\mathrm{X}_{2}\right)$, distribusi $\left(\mathrm{X}_{3)}\right.$ promosi $\left(\mathrm{X}_{4}\right)$. terhadap loyalitas kepuasan (Y2) memberikan nilai 0.6554 yang dapat diinterprestasikan bahwa loyalitas konsumen dapat dijelaskan oleh variabel bauran pemasaran syariah $65,54 \%$ sedangkan sisanya sisanya $34.46 \%$ dijelaskan oleh variabel lain di luar penelitian.

\section{d. Estimate for Path Coefficients,}

Berdasarkan gambar 4 model estimasi akan disajikan nilai koefisien jalur antar variabel,atau besarnya hubungan/pengaruh konstruk laten.dilakukan dengan prosedur Bootrapping. Analisis pengujian dilihat dari hasil tingkat signifikasi 5\% dan nilai $\mathrm{t}$-statistik, apabila nilait-statistik yang didapat > 1,96 maka hasil berpengaruh, sedangkan apabila nilai-t statistik $<1,96$ atau p-value > 5\% maka hasil tidak perpengaruh Hasil pengolahan data koefisien jalur dapat dilihat pada tabel di bawah ini.

Tabel 4

Pengaruh Variabel Laten Independen terhadap Variabel Laten Dependen

\begin{tabular}{|l|c|c|c|c|}
\hline \multicolumn{1}{|c|}{ Variabel Laten } & $\begin{array}{c}\text { Koofiesien } \\
\text { Jalur }\end{array}$ & t-Statistik & $\mathrm{p}$-value & $\begin{array}{c}\text { Signifikansi } \\
\text { jika }<0,05\end{array}$ \\
\hline Terhadap Kepuasan & & & & \\
\hline Produk & 0.5242 & 4.2587 & 0.0000 & Ya \\
\hline Harga & -0.0765 & 0.5859 & 0.5582 & Tidak \\
\hline Distribusi & 0.2171 & 2.2168 & 0.0271 & Ya \\
\hline Promosi & 0.0769 & 0.6171 & 0.5374 & Tidak \\
\hline Terhadap Loyalitas & & & & \\
\hline Produk & -0.0020 & 0.1148 & 0.9087 & Tidak \\
\hline Harga & -0.0176 & 0.1782 & 0.8586 & Tidak \\
\hline Distribusi & 0.1447 & 1.9190 & 0.0556 & Tidak \\
\hline Promosi & 0.0633 & 0.6949 & 0.4875 & Tidak \\
\hline $\begin{array}{l}\text { Kepuasan terhadap } \\
\text { Loyalitas }\end{array}$ & 0.7123 & 7.9023 & 0.0000 & Ya \\
\hline
\end{tabular}

Sumber : diolah penulis (Software SEMPLS3)

Tabel di atas menunjukan hasil perhitungan koefisien jalur, analisis kausalitas variabel dilakukan dengan melihat nilai koefisien beta yang muncul pada keterkaitan suatu variabel, dalam persamaan structural, berdasarkan gambar 1 model estimasi diketahui adanya pengaruh yang meliputi pengaruh langsung ( standardized direct effct) maupun tidak langsung (standardized indirect effct) dan total pengaruh (standardized total effct ), besarnya nilai pengaruh tersebut dapat dilihat berdasarkan perhitungan dibawah dengan menggunakan (Rumus: Menghitung Pengaruh tidak langsung adalah : Jumlah pengaruh langsung 


\section{$X$ terhadap Y2 dengan pengaruh tidak}

langsung X terhadap Y2 melalui Y1 ).

Tabel 5. Rekapitulasi Hasil Perhitungan

Pengaruh Langsung, Pengaruh Tidak Langsung dan Pengaruh Total

\begin{tabular}{|l|c|c|c|}
\hline \multicolumn{1}{|c|}{ Variabel laten } & $\begin{array}{c}\text { Pengaruh } \\
\text { Langsung }\end{array}$ & Pengaruh Tidak Langsung & $\begin{array}{c}\text { Total } \\
\text { Pengaruh }\end{array}$ \\
\hline Tehadap Kepuasan : & & & \\
\hline Produk & 0.5242 & - & 0.5242 \\
\hline Harga & -0.0765 & - & -0.0765 \\
\hline Distribusi & 0.2171 & - & 0.2171 \\
\hline Promosi & 0.0769 & - & 0.0769 \\
\hline Terhadap Loyalitas: & & & \\
\hline Produk & -0.0120 & $0.5242 \times 0.712=0.3731$ & 0.3612 \\
\hline Harga & -0.0180 & $-0.0765 \times 0.712=-0.0547$ & -0.0728 \\
\hline Distribusi & 0.1450 & $0.2171 \times 0.712=0.1546$ & 0.2996 \\
\hline Promosi & 0.0630 & $0.0769 \times 0.712=0.0547$ & 0.1177 \\
\hline
\end{tabular}

Sumber: Diolah Penulis

Tabel di atas menunjukan nilai masing masing variabel, dari angka tersebut menjelaskan keterkaitan antar variabel laten, nilai pengaruh langsung mempunyai angka lebih besar dari pengaruh tidak langsung, maka di dalam model yang dipakai adalah total pengaruh langsung. Berikut ini penjelasan dari masing masing variabel.

Pengaruh Strategi Bauran Pemasaran Syariah terhadap Kepuasan dan Loyalitas Konsumen

\section{H1. Pengaruh Produk terhadap Kepuasan dan Loyalitas Konsumen}

Berdasarkan hasil penelitian Tabel 5 menunjukan bahwa produk berpengaruh positif dan signifikan terhadap kepuasan konsumen dengan nilai sebesar $(0.5242)$ dan nilai t-statistik $(4,2587)>$ t-tabel 1.960 berarti variabel produk terbukti berpengaruh terhadap kepuasaan, semakin baik berkualitas produk Shampo Sariayu Hijab dan bisa memberikan maanfaat kepada rambut konsumen, maka akan semakin besar pula kepuasan yang dirasakan oleh konsumen.

Sangadji (2013) produk adalah segala sesuatu yang dapat ditawarkan kepasar untuk memenuhi kebutuhaan dan keinginan konsumen.
Selain itu Kotler (2014) mendefinisikan produk hasil akhir yang mengandung elemen-lemen fisik, jasa dan lain lain yang simbolis yang dibuat dan dijual oleh perusahaan untuk memberikan kepuasan dan keuntungan bagi pembeli. Hal ini sejalan dengan penelitian yang dilakukan oleh Nastiti (2014) hasil penelitian menunjukkan bahwa dari ketujuh variabel marketing mix yang digunakan variabel paling berpengaruh adalah variabel process dan variabel product.

\section{Pengaruh Produk terhadap loyalitas} Konsumen. Berdasarkan hasil penelitian Tabel 5 menunjukan bahwa hubungan variabel produk dengan loyalitas konsumen mempunyai 2 (dua) pengaruh. Pengaruh langsung dan pengaruh tidak langsung produk terhadap loyalitas. Pengaruh produk secara langsung terhadap loyalitas mempunyai hubungan negatif dan tidak berpengaruh signifikan dengan nilai sebesar 0.0120 dan nilai t- statistik $0.1148<\mathrm{t}$-tabel 1.960 Artinya variabel produk tidakterbukti langsung berpengaruh terhadap loyalitas.

Sedangkan pengaruh tidak langsung variabel produk terhadap loyalitas melalui kepuasan, mempunyai hubungan yang positif dan signifikan dengan angka sebesar 0.3731. Dan total pengaruh dengan angka sebesar 0.3612 . Hal 
Ini berarti kualitas produk menjadi faktor yang paling penting bagi konsumen untuk melakukan pembelian ulang, semakin baik kualitas Shampo Sariyu Hijab dan sesuai dengan harapan konsumen, konsumen akan puas dan akan menjadi pelanggan dan merekomendasikan Shampo Sariayu Hijab kepada orang lain, begitu sebaliknya, maka konsumen tidak akan membeli ulang atau menjadi pelanggan Shampo Sariayu Hijab jika kualitas Shampo Sariayu Hijab jika tidak sesuai dengan harapan mereka. Dan ini sesuai dengan pernyataan Sangadji (2013) produk adalah segala sesuatu yang dapat ditawarkan kepasar untuk memenuhi kebutuhaan dan keinginan. Jika ditinjau dari perspektif syariah jika produk yang ditawarkan mampu memenuhi kebutuhan konsumen, mereka akan puas dan loyal karena di dalam Islam kepuasan diukur berdasarkan kebutuhaan, bukan keinginan dan tetap memakai prinsip yang disyariatkan.

\section{H2. Pengaruh Harga terhadap Kepuasan dan Loyalitas Konsumen}

Berdasarkan hasil penelitian Tabel 5 di atas menunjukan hubungan yang negatif antara variabel harga dan kepuasaan dengan nilai sebesar - 0.0765 dan tidak berpengaruh signifikan terhadap kepuasan konsumen Shampo Sariayu Hijab, dan nilai t-statistik sebesar $0.5859<$ t-tabel 1,960 .

Artinya variabel harga tidak terbukti berpengaruh terhadap kepuasaan konsumen Shampo Sariayu Hijab hal ini berarti variabel harga yang ditawarkan Shampo Sariayu Hijab tidak akan menjadi pertimbangan yang berarti bagi konsumen jika produk yang dibutuhkan sesuai dengan yang diharapkan, dan semakin baik kebijakan harga yang dilakukan PT. Martha Tilaar maka akan semakin besar kepuasan konsumen. Ini sesuai dengan konsep harga ibnu taimiyah (661-728 h/1263-1328m), jika transaksi telah berjalan sesuai dengan ketentuaan yang ada tetapi harga tetap naik, menurut Ibnu Taimiyah ini merupakan kehendak Allah. Dan Kotler (2010) menyatakan bahwa harga juga merupakan salah satu elemen bauran pemasaran yang paling flexible.

Harga dapat diubah dengan cepat dibandingan dengan variabel yang lain. Maksudnya pelaku pasar bukanlah satu satunya faktor yang menentukan harga tetapi ada beberapa faktor lain yang mempengaruhi harga. Yang dalam hal ini dapat disebut dalam hukum alam dalam proses jual beli. Penelitian ini, berbeda dengan penelitian yang dilakukan oleh Satibi et.al (2016) yang mengatakan harga berpengaruh positif terhadap kepuasaan konsumen.

Pengaruh Harga terhadap Loyalitas Konsumen. Berdasarkan hasil penelitin Tabel 4 menunjukan bahwa hubungan variabel harga dengan loyalitas konsumen mempunyai 2 (dua) pengaruh. Pengaruh langsung dan pengaruh tidak langsung terhadap loyalitas . Pengaruh harga secara langsung terhadap loyalitas menunjukan hubungan yang negatif dan tidak berpengaruh signifikan terhadap variabel loyalitas dengan nilai sebesar - 0.018, dan nilai tstatistik $0.1782<\mathrm{t}$-tabel 1.960 . Artinya variabel harga tidak terbukti berpengaruh terhadap Loyalitas. Hal ini berarti produk Shampo Sariayu Hijab belum menjadi kebutuhan tetapi masih sebatas keinginan bagi konsumen.

Sedangkan pengaruh harga secara tidak langsung terhadap loyalitas melalui kepuasan dengan nilai -0.0547 . Dan total pengaruh dengan angka sebesar - 0.0728. Artinya variabel harga tidak terbukti berpengaruh terhadap Loyalitas. Hal ini berarti, harga produk Shampo Sariayu Hijab belum menjadi kebutuhan tetapi masih sebatas keinginan bagi konsumen Shampo Sariayu Hijab, jika sesuatu barang sudah menjadi kebutuhaan bagi konsumen, mereka akan rela berkorban untuk mendapatkan sesuatu barang atau jasa tersebut.

Dari beberapa definisi harga yang disimpulkan menurut para ahli bahwa harga adalah sesuatu yang harus dikorbankan untuk dapat memiliki, menggunakan dan mengkonsumsi barang atau jasa, dalam penelitian ini konsumen tidak akan 
mengkorbankan sesuatu jika tidak bisa memberikan manfaat dari yang sudah mereka keluarkan. Ini sejalan dengan pendapat Tjiptono (2010) dalam sudut pandang konsumen, harga seringkali digunakan sebagai indikator nilai bagaimana harga tersebut dihubungkan dengan manfaat yang dirasakan atas suatu barang atau jasa berapa pun harga yang ditawarkan oleh produsen kepada konsumen jika merasakan nilai dan manfaat terhadap kebutuhan mereka, maka akan tetap melakukan pembeliaan. Zulfa (2010) Loyalitas pelanggan dalam Islam terjadi apabila aktivitas muamalah dapat memberi manfaat yang saling menguntungkan kedua belah pihak, karena terpenuhinya kewajiban serta hak masing-masing melalui penerapan nilai-nilai Islam.

\section{H3. Pengaruh Distribusi terhadap Kepuasan dan Loyalitas Konsumen}

Berdasarkan penelitian Tabel 5, menunujukan hubungan yang positif dan signifikan antara variabel distribusi dengan kepuasan dengan nilai sebesar 0,2171 dengan angka sebesar 2,2168 dan t- statistik >dari ttabel 1,960 . Artinya variabel distribusi terbukti mempunyai hubungan yang positif dan pengaruh signifikan terhadap kepuasan konsumen. Hal ini berarti, distribusi Shampo Sariayu Hijab ini mudah didapatkan oleh konsumen akan berdampak terhadap kepuasan konsumen. Hal ini sesuai dengan Sukatjo dan Radix (2010), menyatakan saluran distribusi merupakan kegiatan memudahkan produk disertai hak pemilik dari produsen ke konsumen.

Tujuan dari fungsi distribusi adalah mempercepat sampainya barang di tangan konsumen atau pasar pada saat yang tepat artinya, jika produk shampo hijab ini mudah didapatkan oleh konsumen akan berdampak terhadap kepuasan konsumenHal ini mendukung pendapat Sukatjo dan Radix (2010), menyatakan saluran distribusi merupakan kegiatan memudahkan produk disertai hak pemilik dari produsen ke konsumen.Tujuan dari fungsi distribusi adalah mempercepat sampainya barang di tangan konsumen atau pasar pada saat yang tepat.
Penelitian ini juga sesuai dengan penelitian yang dilakukan oleh Satibi et al (2016) yang mengatakan tempat berpengaruh positif terhadap kepuasaan konsumen.

Pengaruh Distribusi terhadap Loyalitas KonsumenBerdasarkan hasil penelitian tabel 5 . di atas menunjukan bahwa hubungan variabel distribusi dengan loyalitas konsumen mempunyai 2 (dua) pengaruh. Pengaruh langsung dan pengaruh tidak langsung terhadap loyalitas. Pengaruh langsung menunjukan hubungan yang negatif dengan nilai sebesar 0,1450 dan tidak berpengaruh signifikan terhadap loyalitas dan nilai t-statistik sebesar $0.9190<\mathrm{t}$-tabel 1.960 .

Sedangkan pengaruh tidak langsung distribusi melalui kepuasan konsumen pada Shampo Sariayu Hijab dengan nilai sebesar 0.1546. Dan total pengaruh 0.2996. Artinya distribusi berpengaruh terhadap loyalitas melalui kepuasaan konsumen.Hal ini berarti distribusi Shampo Sariayu Hijab bisa memberikan kepuasaan kepada konsumen yang berdampak terhadap loyalitas konsumen. Jika distribusi barang atau jasa yang di butuhkan konsumen mudah didapatkan maka konsumen akan loyal. karena mereka lebih bisa memperkecil pengorbanan waktu lebih efektif dan Efisien. Hal ini sesuai dengan pernyataan Widjaja (2009) lokasi strategis bagi konsumen akan memperkecil pengorbanan energi dan waktu . Sedangkan menurut Kotler (2009), lokasi atau tempat memberikan kemudahaan yang akan didapat oleh konsumen lokasi atau tempat juga harus bisa memasarkan atau mempromosikan dirinya sendiri. Lokasi atau tempat akan mempromosikan nilai dan citra dari tempat atau lokasi itu sendiri sehingga konsumen bisa membedakanya dengan toko lain.

\section{H4. Pengaruh Promosi terhadap Kepuasan dan Loyalitas Konsumen}

Berdasarkan hasil penelitian Tabel 5 di atas menunjukan bahwa promosi mempunyai hubungan yang positif dan tidak berpangaruh terhadap kepuasaan konsumen, dengan angka sebesar 0.0769 dan t- statistic $0.6171<\mathrm{t}$ - tabel 
1,960 berarti variabel promosi tidak terbukti berpengaruh terhadap kepuasaan konsumen. Hal ini, berarti semakin baik promosi yang disajikan oleh Shampo Sariayu Hijab, maka konsumen akan semakin mengenal Shampo Sariayu Hijab, karena menurut responden promosi yang dilakukan Shampo Sariayu Hijab belum terlalu banyak, dan mereka belum bisa mendapat info tentang produk Shampo Sariayu Hijab sesuai dengan yang mereka inginkan karena kurangnya media iklan,TV, Koran dan media lainya sehingga mereka tidak mengenal Shampo Sariayu Hijab,

Dengan demikian promosi tidak berpengaruh terhadap kepuasan konsumen, Haque et al (2010) menyatakan pemasar perlu mempertimbangkan beberapa faktor dalam menciptakan dan mengantarkan pesan yang efektif. Faktor-faktor ini meliputi, pembatasan tipe media yang digunakan, kemampuan untuk mempromosikan produk-produk tertentu, citra periklanan, grup sosial dan aturan pemerintah. Dan penelitian ini berbeda dengan penelitian yang dilakukan oleh Satibi et al (2016) yang mengatakan promosi mempunyai hubungan positif terhadap kepuasaan konsumen.

Pengaruh Promosi terhadap Loyalitas Konsumen Tabel 5, menunjukan bahwa hubungan variabel Promosi dengan loyalitas konsumen mempunyai 2 (dua) pengaruh. Pengaruh langsung dan pengaruh tidak langsung terhadap loyalitas. Pengaruh langsung menunjukan hubungan yang positif angka sebesar 0.0630 dan tidak berpengaruh signifikan terhadap loyalitas dengan nilai t-statistik sebesar $0.6949<\mathrm{t}$-tabel 1.960 .

Sedangkan pengaruh tidak langsung terhadap loyalitas melalui kepuasaan dengan nilai sebesar 0.0547. Dan total pengaruh dengan nilai sebesar 0.1177 . Artinyavariabel promosi tidak terbukti berpengaruh terhadap loyalitas. Hal ini berarti bahwa responden akan loyal kepada Shampo Sariayu Hijab melalui kepuasan jika informasi yang diterima bisa memberikan manfaat kepada mereka. Hal ini sesuai dengan pendapat Clow (2010),Promosi merupakan elemen penting dari strategi pemasaran perusahaan, yang merupakan jenis komunikasi dengan konsumen berkenaan dengan penawaran produk, dan ini adalah cara untuk mendorong pembelian atau penjualan produk atau pelayanan.

\section{H5. Pengaruh Kepuasan terhadap Loyalitas}

Tabel 5, menunjukan hubungan yang positif dan pengaruh yang signifikan antara variabel kepuasan terhadap loyalitas , dengan nilai sebesar 0,7123 dan 7,9023, dan t-statistik dan ttabel $>1,960$. Ini sesuai dengan pendapat Ramiz, (2014), menyatakan kepuasan konsumen sebagai evaluasi pasca konsumsi terhadap produk atau layanan dalam hal sikap positif atau netral atau negatif terhadap produk atau layanan yang dihasilkan dari korespondensi yang menguntungkan antara harapan konsumen dan pengalaman dengan perusahaan atau produknya.

Sedangkan menutut Zulfa (2010) loyalitas pelanggan dalam Islam terjadi apabila aktivitas muamalah itu dapat memberi manfaat yang saling menguntungkan kedua belah pihak, karena terpenuhinya kewajiban serta hak masing-masing melalui penerapan nilai-nilai Islam.

Dan menurut Mao (2010) konsumen yang puas akan memiliki loyalitas yang lebih besar, yang memungkinkan kesempatan untuk melakukan pembelian ulang di masa depan, sedangkan menurut Ganiyu (2012) menyatakan bahwa kepuasan konsumen dan loyalitas tidak berhubungan langsung karena terdapat perbedaan besar antara kepuasan dan loyalitas, dimana kepuasan merupakan kondisi konsumen yang pasif sedangkan loyalitas merupakan kondisi konsumen yang aktif.

\section{Kesimpulan}

Berdasarkan data yang diperoleh dalam penelitian ini. Dapat diambil beberapa kesimpulan :

1. Adanya hubungan yang positif dalam bauran pemasaran syariah terhadap kepuasan dan loyalitas konsumen, yang bisa memberikan keselarasan kepada stockholder. Persepsi konsumen yang baik terhadap shampo hijab, 
dan pengaruh yang paling dominan adalah produk dan promosi dan distribusi

2. Dalam penelitian ini ditemukan bahwa konsumen tidak merasa puas terhadap shampo hijab melihat dari angka $r$ Square hanya dengan 0,4394 variabel independen hanya mampu memberikan pengaruh kepada konsumen dibandingkan dengan angka loyalitas 0,6554, artinya lebih tinggi angka loyalitas dibandingkan dengan kepuasaaan dapat diartikan bahwa konsumen tetap akan loyal terhadap shampo hijab tetapi belum tentu puas, dikarena adanya beberapa faktor lain ,diantara jika melihat dari jawaban dan tanggapan responden mereka lebih memetingkan nilai -nilai syariah dalam suatu produk dari rasa puas itu sendiri terhadap shampo hijab dengan ini tidak terbukti kebenarannya bahwa konsumen akan puas kemudian baru akan loyal terhadap produk shampo hijab, tetapi dalam penelitian ini penuliskan menemukan bahwa konsumen tidak puas terhadap produk shampo hijab sariayu namun mereka akan tetap loyal, karena adanya suatu nilai yang diyakinan akan kehalal dari produk shampo hijab tersebut.

Pemilihaan karakteristik brand ambasor yang bisa mewakili produk itu sendiri dari data penelitian ini brand ambasador yang dijadikan pilihaan ada 2 orang, adalah Ali Subando dengan persentase $55 \%$ responden memilih dan Rahel Maryam 45\% responden.

\section{Daftar Pustaka}

Arhaam I.(2010). Perspectives on Marketing, (Journal of Islamic Marketing Volume 1 No.2,) hlm 164.

Antonio MS. (2010). Ekslopedia Leadership Manajemen Muhammad Saw"The Super Leader Super Manager"jilid 2

Assauri S. (2004). Manajemen Produksi dan Operasi. Jakarta FEUI.

Alma B. (2004). Manajemen Pemasaran dan Pemasaran Jasa, Edisi Revisi, Bandung:Penerbit Alfabeta.
Assauri S. (2004). Manajemen Pemasaran Dasar Konsep \& Strategi.Jakarta: PT. Raja Grafindo Persada.

Abdullah S, Susanto TD. (2015). Statiska Tanpa Stres:TransMedia Pustaka.

Afrida SM. (2013). Pengaruh Bauran Pemasaran terhadap Kepuasan Konsumen, Jurnal Ilmu \& Riset Manajemen vol. 2 no. 9

Basu S, Irawan. (2005). Manajemen Pemasaran Modern. Yogyakarta.Liberty.

Baker AS. (2011). The Principles of Islamic Marketing, Printed and bound in Great Britain by the MPG Books Group,UK.

Chan YY, Shaheen M. (2016). Factor that influences consumers' brand loyalty towards cosmetic products $b$ Professor, INTI International University, Malaysia Journal of Marketing Management and Consumer Behavior, Vol. 1, Issue 1 (2016) 12-29.

Endah NH. (2014). Perilaku Pembelian Kosmetik Berlabel Halal oleh Konsumen Indonesia consumers's purchasing behavior toward halal labeled

Cosmetics in indonesia Peneliti Pusat Penelitian Ekonomi, LIPI, Jurnal

Ekonomi dan Pembangunan Vol 22, No.1.

Erwandi T. (2013). Harta Haram Muamalat Kontemporer, Yogyakarta: Penerbit PT. Berkat Mulia Insani

Hair R, Sarstedt. (2011). PLS-SEM indeed a silver bullet. Journal of Marketing Theory and Practice, vol. 19, no. 2 (spring 2011), pp. 139-151. (C) 2011 M.E. Sharpe, In. Hamza SK. (2014). The Influence of Brand Loyalty on osmetics Buying Behavior of UAE Female Consumers Marketing Department, Faculty of

Business Middle East University, Amman, Jordan.

Huda N.(2012). Pengenalan Ekslusif Ekonomi Islam (Kencana Prenada Group),

Jonathan S.(2008). Mengenal Amos Untuk Analisis Structural Equation Model (SEM), Jakarta.

Kartajaya H, Sula M S. (2005). Syariah Marketing. Penerbit Mizan. 
Karim A, Sahroni O.(2015) Maqashid Bisnis \& Keuangan Islam. Sintesis Fikih dan Ekonomi. Karim A, Azwar.(2006). Sejarah Pemikiran Ekonomi Islam edisi ketiga,

Jakarta:PT. Raja Grafindo Persada.

Karim A,Sahroni O.(2015). Riba Gharar dan Kaidah-Kaidah Ekonomi Syariah

Analisis Fikih \& Ekonomi. Jakarta: PT RajaGrafindo Persada.

Kotler P, Kevin LK. (2007). Manajemen Pemasaran. Edisi Kedua Belas. Indeks: Jakarta.

Kamajeet K. (2014). Predicting Working Women Purchasing Behaviour of

Malaysian Halal Cosmetic Products by Using Theory of Planned Behaviour Infrastructure University of Kuala Lumpur.

Lily H, Lusia O, Sabu G.(2014).Pengaruh Persepsi Kualitas Produk

terhadap Keputusan Pembelian The Body Shop. Lovelock C.H, Wright L.K.(2007). Manajemen

Pemasaran Jasa. Edisi Bahasa

Indonesia. Jakarta: PT Indeks.

Mursid. (2014). Manajemen Pemasaran Jakarta:Penerbit BUMI AKSARA

Muhammad. (2004). Ekonomi Mikro dalam Perspektif IslamYogyakarta.

Mahabub A, Shariful H.(2011). Marketing: An Islamic Perspective World Journal of Social Sciences Vol. 1. No. 3. July 2011. Pp. 71-81. Manan MA. (1997). Teori dan Praktek Ekonomi Islam(Yogyakarta): Dana

Bhakti Prima Yasa.

Mustofa E.(2012). Pengenalan Ekslusif Ekonomi Islam. Jakarta: Prenada Media Grup.

Najib M. (2015). Manajemen pemasaran Internasional Strategi Membangun Keunggulan Bersaing di Pasar Global.cet.1, Bogor: PT Penerbit IPB Press.

Nurgiyantoro B.(2015). Statistik Terapan. Gadjah Mada University Press.
Narimawati, Jonathan S.(2007). Structural Equation Model (SEM) Dalam Riset Ekonomi: Menggunakan LISREL. Yogyakarta: Penerbit Gava Media.

Rachmawati.(2011). Peranan Bauran Pemasaran Marketing Mix Terhadap Peningkatan Penjualan (Sebuah Kajian Terhadap Bisnis Restoran). Jurnal Kompetensi Teknik 2(1): 145-149.

Rangkuti F. (2011). Riset Pemasaran, PT GramediaBuilding.

Siswoyono HParwoto W. (2012). Structural Equation Modeling.

Tanjung H.(2013). Metodologi Penelitian Ekonomi Islam. Jakarta: Gramata Publising.

Yudhistira P, Setiawan B, FudholiA, Satibi.(2016). Pengaruh Bauran Pemasaran terhadap Kepuasan dan Loyalitas Pelanggan Produk (Influence of Marketing Mix Satisfaction and Loyalty Products Customers), Universitas Gadjah Mada, Yogyakarta Jurnal Manajemen dan Pelayanan Farmasi P-ISSN: 2088-8139 EISSN: 2443-2946.

Wijaya N, Dharmayanti D. (2014). Analisa Efektivitas Iklan Kosmetik Wardah dengan Menggunakan Consumer Decision Model (cdm)jurnal Manajemen Pemasaran Petra, vol 2.

(http://www.marthatilaargroup.com/id/berita/beri ta-terkini/565-unpad-tandatangani-kerjasama-dengan-pt-martina-berto,-tbk.html).

(http://www.marthatilaargroup.com/id/berita/beri ta-terkini/577-sertifikasi-halal,- bentukkomitmen-martha-tilaar-group-padakonsumen-indonesia.html).

Sumber:https://almanhaj.or.id/3654-curangdalam-timbangan-dan-takaran-mengundangkerusakan-di-dunia-dan-celaka-diakherat.html. 